\title{
PERKEMBANGAN FISIK MOTORIK KASAR ANAK MELALUI PERMAINAN TRADISIONAL “JALAN TEMPURUNG”
}

\author{
Wiwin Kaoci', Bahran Taib², Dewi Mufidatul Ummah ${ }^{3}$ \\ Universitas Khairun \\ Fakultas Keguruan Dan Ilmu Pendidikan \\ Jl.Bandara Sultan Babulla Kota Ternate Utara, Kode Pos 53 Ternate 97728 \\ Telepon (0921)3110905-Faksimili 0921-3110901 \\ Email: wiwinkaoci17@gmail.com 1, taibbahar4685@gmail.com ${ }^{2}$, athala@gmail.com ${ }^{3}$
}

\begin{abstract}
Abstrak: Perkembangan fisik motorik kasar pada anak usia dini adalah gerakan tubuh yang menggunakan otot-otot besar atau seluruh anggota tubuh, yang dipengaruhi oleh tahapan perkembangan anak. Perkembangan fisik motorik kasar anak meiputi kemampuan melompat, berlari, mengangakat, melempar, keseimbangan, kekuatan, kelincahan, dan lain-lain. Banyak permainan yang dapat diterapkan dalam perkembangan fisik motorik kasar anak, salah satunya yaitu dengan permainan tradisional "jalan tempurung". Dalam permainan tradisional "jalan tempurung" bahan-bahannya sangat mudah diperoleh yakni terbuat dari buah kelapa tua yang dibelah dua lalu bersihkan dan dibuat lubang untuk memasukkan tali, dan diberi pengait sepotong kayu atau bambu sehingga tali teriikat dengan kuat. Adapun cara permainan tradisional "jalan temprung" yakni kedua kaki masing-masing diletakkan pada masing-masing tempurung dengan ibu jari dan telunjuk pada jari kaki menjepit tali, sementara itu tangan memegang tali dan bersiap-siap untuk berjalan. Metode yang digunakan dalam penelitian ini dengan pendekatan studi literature (library research). Dari hasil penelitian dapat disimpulkan bahwa dengan permainan tradisional "jalan tempurung" dapat mengembangkan perkembangan fisik motorik kasar anak.
\end{abstract}

Kata Kunci: Mototik Kasar, Permainan Tradisional, “Jalan Tempurung”,

Abstrack: Gross motor physical development of early childhood is body movement with big muscles or all part of body that influenced by stages of child develop. Gross motor physical development of early childhood comprise ability to jump, run, lift, throw, body balance, strength, agility, etc. There are many games for gross motor physical development, one of them is traditional game, "Jalan Tempurung". "Jalan Tempurung" needs very simple material for play, coconut sheel. Clean the coconut sheel then make a hole for insert rope. Give a wooden or bamboo hook so the rope tie tightly. For play "Jalan Tempurung", put feet on each sheel with thumb and forefinger clasping the rope while your hands holding the rope and get ready to walk. The research method used is library research. The conclusion is traditional game "Jalan Tempurung" can enhance gross motor physical development of early childhood.

Key words: gross motor, traditional game, "Jalan Tempurung"

\section{A. Pendahuluan}

Menurut Undang-Undang Nomor 20 Tahun 2003 tentang Sistem Pendidikan Nasional, Pendidikan Anak Usia Dini (PAUD) adalah suatu upaya pembinaan yang ditujukan kepada anak sejak lahir sampai dengan usia enam tahun yang dilakukan melalui pemberian rangsangan pendidikan untuk membantu pertumbuhan dan perkembangan jasmani dan rohani agar anak memiliki kesiapan dalam memasuki pendidikan lebih lanjut. Pendidikan anak usia dini (PAUD) merupakan suatu upaya pembinaan yang ditujukan kepada anak sejak usia dini (0-6 tahun) dilakukan melalui pemberian rangsangan pendidikan untuk membantu pertumbuhan dan 
perkembangan jasmani dan rohani, agar anak memiliki kesiapan dalam memasuki pendidikan dasar dan kehidupan tahap berikutnya.

Kegiatan yang sangat penting dalam kehidupan anak-anak adalah tempat bermain, karna duni anak adalah bermain sambil belajar. Bermain merupakan satu kesatuan yang tidak bisa dipisahkan dari anak, bagi orang dewasa bermain mungkin berfungsi sabagai pengisi waktu saja. Sedangkan berbeda bagi anak, bermain menjadi salah satu kegiatan yang sanagat disukai oleh anak sekaligus sebagai cara untuk menambah pengetahun dan sarana dalam setiap tahap-tahap perkembangan anak.

Vigotsky, dalam Turyani dan Wondal (2018:29) menggambarkan bermain sebagai perkembangan utama selama anak-anak, dan dia membahas bagaimana situasi imajiner, anak-anak mendapatkan kesenangan yang maksimal dari menundukan diri dari peraturan. Dengan kata lain, kita bisa mengerti atribut penting permainan dengan sedemikian rupa sehingga aturan main menjadi motif tindakan. Mengingat penekanan Vigotsky pada imajinasi, bermain sebagai kesempatan bagi seorang anak untuk menjadi pencipta peraturan dan pemain majinatif. Saat bermain, anak-anak juga mengeksplorasi imajinatif, skenario kreatif mereka yang menarik dan bermakna.

Permainan merupakan suatu kegiatan yang memberikan anak kebebasan untuk belajar dan menerima pengalaman baru.Permainan juga dapat diartikan suatu aktivitas yang dilakukan secara individu maupun kelompok, dalam permainan tersebut bisa menggunakan media atau alat permainan. Permainan juga dapat mengembangakan pengetahuan dan berbagai aspek-aspek perkembangan anak. Ismail dalam Muslimah (2018:8) mendefinisikan permainan sebagai suatu aktifitas yang membantu anak mencapai perkembangan yang utuh, baik fisik, intelektual, sosial, moral dan berhitung. Jadi permainan adalah suatu aktifitas yang dilakukan oleh beberapa anak untuk mencari kesenangan yang dapat membentuk kepribadian anak dan membantu anak mencapai perkembangan fisik, intelektual, sosial, moral dan berhitung.

Permainan tradisional adalah permainan sederhana yang tumbuh dan berkembang di daerah tertentu, berasal dari kekayaan dan kearifan lokal daerah, serta mengandung nilai-nilai dan kebudayaan leluhur yang diwariskan secara turun temurun pada setiap generasi. Permainan tradisional biasanya merupakan ciri khas dari daerah tersebut dengan makna filosofis dan pendekatan yang mendalam.

Jalan tempurung adalah bahasa lokal Maluku Utara sedangkan dalam bahasa Indonesia di sebut egrang bathok kelapa, tempurung kelapa adalah permainan tradisional yang dibuat menggunakan alat dan bahan sederhana berupa tempurung kelapa yang dilubangi lalu diberi tali pada tengah tempurung. Kemudian dimainkan dengan cara meletakkan kaki di atas masing-masing tempurung dan melangkah seperti layaknya berjalan.

Perkembangan fisik motorik kasar pada anak usia dini merupakan perkembangan yang sangat penting bagi anak. Karena dari gerakan fisik motorik kasar anak dapat melatih gerakan otot-otot besar dan mengkoordinasi antara mata, tangan dan kaki. Dengan mengkoordinasi mata, tangan dan kaki sudah baik maka anak sudah bisa melakukan kegiatan fisik motorik kasar seperti. Melompat, berlari, mengangkat, melempar, keseimbangan, kekuatan, kelincahan dan lain-lain sebagainya. Setiap anak mencapai perkembangan fisik motorik kasar yang optimal, anak harus mendapatkan stimulasi yang baik. Untuk mengembangkan perkembangan fisik motorik kasar anak dapat dilakukan dengan kegiatan permainan tradisional 'jalan tempurung' 


\section{B. Metode}

Metodologi yang digunakan dalam penelitian ini dengan pendekatan studi literatur (library reseach). Menurut Zeed Mestika, dalam Zahriani (2020:4) menyatakan bahwa metode penelitian dengan pendekatan studi literature merupakan penelitian yang serangkaian kegiatannya dengan metode pengumpulan data pustaka, buku-buku, serta tulisan yang terkait dengan judul penelitian tersebut, dari perpustakaan kamus online (contoh wikipedia) dan internet yang dapat memperkuat naskah yang akan dipublikasikan.

\section{Pembahasan}

\section{Perkembangan Fisik Motorik Kasar Pada Anak}

Perkembangan motorik diartikan sebagai perkembangan dari unsur kematangan pengendalian gerak tubuh dan otak sebagai pusat gerak. Gerakan ini secara jelas di bedakan menjadi gerak kasar dan halus. Keadaan sekitar sangat berpengaruh terhadap peningkatan kemampuan motorik anak, terutama lingkungan keluarga.Selain itu motoric juga berarti perkembangan gerak pengendalian jasmaniah melalui kegiatan pusat syaraf, urat syaraf dan otot-otot yang terkoordinasi Hurlock, dalam Rinasari (2013:11).

Novan Ardy Wiyani, dalam Roftah (2019:20) fisik dapat diartikan sebagi jasmani, badan, dan tubuh. Sedangkan motorik diartikan dengan penggerak. Perubahan yang terjadi pada tubuh atau jasmani seseorang dapat mempengaruhi keterampilan gerak tubuhnya. Jadi perkembangan fisik motorik anak usia dini dapat diartikan sebagai perubahan bentuk tubuh pada anak yang berpengaruh terhadap keterampilan gerak tubuhnya.

Menurut Agoes Dariyo, dalam Hasana (2016:720) mengemukakan bahwa yang paling menonjol dan nampak pada diri individu adalah terjadinya perubahan fisik. Hal ini terbukti dengan adanya perubahan fisik yang ternyadi sangat cepat yakni sejak masa konsepsi hingga masa kelahirannya. Kemudian dilanjutkan masa bayi, anak-anak, remaja dan dewasa.

Menurut Julkifli, dalam Mulyani (2018:18-19) perkembangan motorik yakni gerakan-gerakan tubuh yang dimotori dengan kerjasama antara otot, otak dan saraf. Ciri-ciri gerakan motoris: gerak yang dilakukan tidak sengaja, tidak ditujukan untuk maksud-maksud tertentu. Gerak yang dilakukan tidak sesuai untuk mengangkat benda dan gerak serta. Sementara itu, Keogh menjelaskan bahwa perkembangan gerak adalah perubahan kompetensi atau kemampuan gerak dari mulai bayi (infancy) sampai masa dewasa (adulthoud) serta melibatkan berbagai aspek perilaku manusia, kemampuan gerak dan aspek perilaku yang ada pada manusia mempengaruhi perkembangan gerak dan perkembangan gerak sendiri mempengaruhi kemampuan dan perilaku manusia.

Menurut Hasninda, dalam Novitasari (2019:7) menyatakan motorik kasar adalah gerakan tubuh yang menggunakan sebagian besar atau sebagian anggota tubuh yang dipengaruhi oleh kematangan anak itu sendiri. Suyadi mengutip pendapat Laura E. Berk, dalam Wiyani (2015:27) motorik kasar adalah gerak anggota badan secara kasar atau keras.mengungkapkan bahwa semakin anak menjadi dewasa dan kuat tubuhnya atau besar, maka gaya geraknya sudah berada pula. Hal ini mengakibatkan pertumbuhan otot yang semakin membesar dan menguat. Pembesaran dan penguatan otot-otot badan tersebut menjadikan keterampilan baru selalu bermunculan dan semakin bertambah kompleks. 
Berdasarkan pendapat di atas, penulis menyimpulkan bahwa fisik motorik kasar adalah pengendalian gerakan tubuh yang berhubungan dengan otot-otot besar, misalnya berlari, melompat, melempar dan lain-lain sebagainya.

\section{Tujuan Perkembangan Fisik Motorik Kasar Pada Anak}

Perkembangan motorik kasar di TK bertujuan untuk memperkenalkan dan melatih gerakan kasar, meningkatkan kemampuan mengelolah, mengontrol gerakan tubuh dan koordinasi, serta meningkatkan keterampilan tubuh dan cara hidup sehat, sehingga dapat menunjang pertumbuhan jasmani yang sehat, kuat dan terampil. Sesuai dengan tujuan perkembangan jasmani tersebut, anak didik dilatih gerakan-gerakan dasar yang akan membantu perkembangan motoriknya kelak. Depdiknas, dalam Riza (2018:45) perkembangan kemampuan dasar anak dapat dilihat dari kemampuan motoriknya. Sehingga guru-guru TK perlu membantu membantu mengembangkan keterampilan mptorik anak dalam hal memperkenalkan dan melatih gerakan motorik kasar anak, meningkatkan kemampuan mengelolah, mengontrol gerakan tubuh dan koordinasi, serta meningkatkan keterampilan tubuh dan cara hidup sehat sehingga dapat menunjang pertumbuhan jasmani yang kuat, sehat dan terampil. Kompetensi anak TK yang diharapkan dapat dapat dikembangkan guru saat anak memasuki lembaga prasekolah/TK adalah anak mampu melakukan aktivitas motoriik secara terkoordinasi dalam rangka kelenturan dan kesiapan untuk menulis, keseimbangan, dan melatih keberanian.

Menurut Samsudin, Dalam Baan (2020:18) perkembangan motorik kasar bagi anak usia dini memiliki tujuan yakni memperkenalkan gerakan kasar, melatih gerakan kasar, meningkatkan kemampuan mengelolah, mengontrol gerakan dan koordinasi, serta meningkatkan keterampilan dan cara hidup sehat.

Menurut Sumantri, dalam Novitasari (2019:8) motorik kasar memiliki beberapa tujuan yaitu 1) mampu meningkatkan keterampilan gerak; 2) mampu memilihara dan meningkatkan kebugaran jasmani; 3) mampu menanamkan sikap percaya diri; 4) mampu bekerja sama dan 5) mampu berperilaku disiplin, jujur, dan sportif.

\section{Gerak Dasar Motorik Kasar Pada Anak}

Menurut Maimunah Hasan, dalam Rinasari (2013:26-27) mengatakan bahwa terdapat empat macam gerak dasar motorik kasar pada anak, diantaranya adalah sebagai berikut:

a. Berjalan

Pada motorik fase ini, yang harus diberikan stimulasi adalah kemampuan berdiri, berjalan ke depan, berjalan ke belakang, berjalan berjingkat, melompat atau meloncat, berlari, berdiri satu kaki, dan menedang bola. Berjalan harus dikuasai anak saat berusia satu tahun, sedangkan berdiri satu kaki dikuasai anak saat berusia dua tahun.Untuk kemampuan berjalan perkembangan yang harus dikuatkan adalah keseimbangan dalam berdiri.

b. Lari

Perkembangan lari akan mempengaruhi perkembangan lompot, lempar dan kemampuan konsentrasi anak. Pada tugas perkembangan ini, dibutuhkan kseimbangan tubuh, kecepatan gerak kaki, ketepatan empat pola kaki bertumpu pada tumit, telapak kaki mengangkat kemudian bertumpu pada ujung-ujung jari kaki, kaki berayun, dan mengayung kaki menampak pada alas, serta perencanaan gerak.

c. Lompat 
Kemampuan dasar yang harus dimiliki anak pada fase melompat adalah keseimbangan yang baik, kemampuan koordinasi motorik, dan perencanaan gerak. Jika anak tidak kuat dalam perkembangan melompat, biasanya akan menghadapi kesulitan dalam sebuah perencanaan tugas yang terorganisasi (tugas-tugas yang membutuhkan kemampuan motor planning).

d. Lempar

Pada fase melempar yang berperan adalah sensoris motor keseimbangan, rasa sendi serta visual. Peran yang paling utama adalah propriosepsi, yaitu bagaimana sendi merasakan suatu kegiatan atau aktivitas. Misalnya ketika anak melempar bola, seberapa kuat atau lemah lemparannya, supaya bola masuk ke dalam keranjang atau sasaran yang dituju.

\section{Unsur-Unsur Keterampilan Motorik Kasar Pada Anak}

Unsur-unsur keterampilan motorik kasar meliputi:

\section{a. Kekuatan}

Kekuatan adalah kemampuan seseorang untuk membangkitkan tegangan terhadap suatu tahanan. Derajat kekuatan otot tersebut pada umumnya berbeda untuk setiap orang kekuatan otot dapat dikembangkan melalui latihan-latihan otot melawan tahanan yang ditingkatkan sedikit demi sedikit.Kekuatan merupakan hasil kerja otot yang berupa kemampuan untuk mengangkat, menjinjing, menahan, mendorong atau menarik beban.

b. Daya tahan

Daya tahan adalah kemampuan tubuh mensuplai oksigen yang diperlukan untuk melakukan suatu kegiatan. Apabila seseorang melakukan kegiatan latihan khusus untuk memperbaiki daya tahan tubuhnya maka akan terjadi peningkatan kapiler-kapiler jaringan otot. Daya tahan otot adalah kemampuan otot atau sekelompok otot untuk bertahan melakukan suatu kegiatan dalam waktu yang lama.

c. Kecepatan

Dapat diberikan dengan kegiatan latihan yang serba cepat, seperti lari dengan jarak yang pendek.

d. Kelincahan

Kelincahan adalah kemampuan seseorang untuk bergerak secara cepat. Komponen kelincahan adalah berikut ini:

1) Melakukan gerak perubahan arah secara cepat

2) Berlari cepat, kemudian berhenti secara mendadak

3) Kecepatan bereaksi

e. Kelentukan

Kelentukan adalah kualitas yang memungkinkan suatu segmen bergerak semaksimal mungkin menurut kemungkinan rentang geraknya. Fleksibilitas seseorang ditentukan oleh kemampuan gerak dari sendi-sendi. Makin luas ruang gerak sendi-sendi makan baik fleksibilitas seseorang

f. Koordinasi

Koordinasi gerak merupakan kemampuan yang mencakup dua atau lebih kemampuan perceptual pola-pola gerak. Termasuk kemampuan gerak sebagai berikut:

1) Koordinasi mata dan tangan, yang berhubungan dengan kemampuan memilih suatu objek dan mengkoordinasikannya (objek dilihat dari gerakan-gerakannya yang diatur). Contohnya dalam permainan menangkap bola, koordinasi mata dan tangan mengkehendaki pengamatan yang tepat. 
2) Koordinasi mata dan kaki, yang berhubungan dengan kemampuan melakukan suatu gerakan berdasarkan penglihatan dan gerak badan bagian bawah, misalnya menendang bola.

g. Ketepatan

Kegiatan yang dapat dilakukan, misalnya anak melempar bola kecil kesasaran tertentu atau memasukkan ke dalam keranjang.

h. Keseimbangan

Keseimbangan bisa diklasifikasikan menjadi dua macam, yaitu keseimbangan statik dan keseimbangan dinamik.Keseimbangan statik adalah kemampuan mempertahankan posisi tubuh tertentu untuk tidak bergoyang atau roboh. Sedangkan keseimbangan dinamik adalah kemampuan untuk mempertahankan tubuh agar tidak jatuh pada saat sedang melakukan gerakan

\section{Fungsi Perkembngan Fisik Motorik Kasar Pada Anak}

Fungsi perkembangan motorik kasar pada anak TK (Depdiknas, 2004:2), dalam Erlinda (2014:29) sebagai berikut:

a. Meltih kelenturan dan koordinasi otot jari dan tangan.

b. Memacu pertumbuhan pengembangan fisik/motorik, rohani dan kesehatan anak.

c. Membentuk, membangun, dan memperkuat tubuh anak.

d. Melatih keterampilan/ketangkasan gerak dan berpikir anak.

e. Meningkatkan perkembangan emosional anak.

f. Meningkatkan perkembangan sosial anak.

g. Menumbuhkan perasaan menyenangi dan memahami manfaat kesehatan pribadi.

\section{Permainan Tradisional}

Permainan tradisional merupakan sebuah permainan yang berasal dari beberapa daerah tertentu yang biasanya merupakan ciri khas dari daerah tersebut dengan makna filosofis dan pendekatan yang mendalam. Permainan tradisional biasanya mengutamakan kerjasama dan kekompakan yang menjadi ciri khas budaya tradisional seperti gotong royong dan musawara.

Menurut Khasanah dkk, dalam Purwadi (2016:5) permainan tradisional yaitu permainan turun temurun dari orang tua yang ada di lingkungan mereka tinggal. Permainan tradisional menjadi bagian dari berbagai jenis pendorong yang kuat bagi perkembangan anak. Selain itu ditemukan pula bahwa pada permainan tradisional yang ada di masyarakat memilki nilai-nilai kearifan lokal yang perlu dijaga keberadaannya, Misal: jenis permainan tradisional yang dapat melatih ketangkasan, kekuatan fisik motorik, keberanian, keterampilan, dan lain sebagainya.

Menurut Nurcahyo, dalam Sari (2019:15) permainan tradisional merupakan suatu jenis permainan yang ada pada daerah tertentu yang didasarkan pada nilai budaya daerah tersebut. Permainan tradisional dapat digunakan sebagai sumber kegiatan yang menyenangkan untuk anak.

Pendapat lain dari Rahmawati, dalam Masruroh (2018:8) menyatakan bahwa permainan tradisional anak adalah proses melakukan kegiatan yang menyenangkan hati anak dengan mempergunakan alat sederhana sesuai dengan potensi yang ada dan merupakan hasil penggalian budaya setempat menurut gagasan dan ajaran turun temurun dari nenek moyang. Pada perkembangan selanjutnya permainan tradisional 
sering dijadikan sebagai jenis permainan yang memiliki ciri kedaerahan asli serta disesuaikan dengan tradisi budaya setempat.

Direktorat Nilai Budaya, dalam Kurniati (2016:2) menjelaskan bahwa permainan rakyat tradisional pada dasarnya digolongkan menjadi dua, yaitu permainan untuk bermain dan permainan untuk bertanding, permainan untuk bermain lebih bersifat untuk mengisi waktu senggang. Sedangakn permainan untuk bertanding kurang memiliki sifat tersebut. Permainan cirri-cirinya: terorganisasi, bersifat kompetitif, dimainkan paling sedikit oleh dua orang, mempunyai criteria yang menentukan siapa yang menang dan yang kalah, serta mempunya peraturan yang diterima bersama oleh pesertanya.

Berdasarkan beberapa pendapat di atas, penulis menyimpulkan bahwa permainan tradisional adalah permainan sederhana yang tumbuh dan berkembang di daerah tertentu, berasal dari kekayaan dan kearifan lokal daerah, serta mengandung nilai-nilai dan kebudayaan luhur yang diwariskan secara turun temurun pada setiap generasi.

\section{E. Permainan Jalan Tempurung}

Permainan jalan tempurung adalah bahasa lokal Maluku Utara, sedangkan dalam bahasa Indonesia di sebut dengan Egrang bahtok kelapa. Permainan ini sangat disukai oleh anak-anak, dan sangat mudah biasanya dimainkan secara individu maupun berkelompok. Dalam permainan tersebut banyak manfaat yang diperoleh anak seperti anak merasa gembira, mengasah kreativitas anak, serta melatih motorik kasar anak.

Madyawati, dalam Laely (2015:35). Egrang tempurung kelapa adalah permainan tradisional Indonesia yang belum diketahui secara pasti dari mana asalnya, tetapi dapat dijumpai di berbagai daerah dengan nama yang berbeda-beda, seperti tengkak-tengkak (Sumatra barat), ingkau (Bengkulu), jangkungan (Jawa Tengah), atau batungkau (Kalimantan Selatan). Kata egrang sendiri berasal dari bahasa lampung yang berarti terompah pancung yang terbuat dari bamboo bulat panjang. Egrang terbuat dari batang bambu dengan panjang ukuran lebih 2,5 meter. Sekitar $50 \mathrm{~cm}$ dari bawah dibuat tempat berpijak kaki yang rata dengan lebar kurang lebih $20 \mathrm{~cm}$. sedangkan egrang tempurung kelapa terbuat dari dua tempurung kelapa yang dihubungkan dengan tali. Cara memainkannya dengan berlomba berjalan menggunakan egrang tempurung kelapa tersebut dari satu sisi lapangan ke sisi lainnya. Permainan yang paling cepat dan tidak terjatuh dialah pemenangnya.

Menurut Mulyani, dalam Masruroh (2018:10) adalah egrang bathok kelapa yang dibuat dari bahan dasar tempurung kelapa yang tengahnya dilubangi lalu diberi tali plastik atau dadung pada tengah tempurung untuk memainkannya. Permainannya pun cukup mudah, kaki tinggal diletakkan ke atas masing-masing tempurung, kemudian kaki satu diangkat, sementara kaki lainnya tetap bertumpu pada bathok lain di tanah seperti layaknya berjalan.

Cahyono dalam Purwadi (2016:5) mengukapkan selain menenal egrang dari banbu, anak-anak masyarakat jawa masa lalu mengenal egrang bathok. Egrang jenis terakhir ini dibuat dari bahan dasar tempurung kelapa yang dipadu dengan tali plasting atau dadung. Permainanpun cukup mudah, kaki tinggal diletakkan ke atas masing-masing tempurung, kemudian kaki satu diangkat, sementara kaki lainnya tetap bertumpu pada bathok lain di tanah seperti layaknya berjalan. Anak sekarang memang tidak harus memainkan kembali permainan tradisional, termasuk dolanan egrang 
bathok kelapa. Namun paling tidak generasi tua ini bisa mengenalkan kepada generasi muda sekarang. Tentu dengan harapan generasi muda sekarang bisa mengenal sejarah kebudayaan nenek moyangnya, termasuk dalam lingkup permainan tradisional dan akhirnya bisa menghargai karya dan identitas dari bangsanya sendiri walaupun teknologi yang diterapkan kala itu sangat sederhana.

Berdasarkan pendapat di atas, penulis menyimpulkan bahwa egrang tempurung kelapa adalah permainan tradisional yang dibuat menggunakan alat dan bahan sederhana berupa tempurung kelapa yang dilubangi lalu diberi tali pada tengah tempurung. Kemudian dimainkan dengan cara meletakkan kaki di atas masing-masing tempurung dan melangkah seperti layaknya berjalan.

\section{Langkah-Langkah Pembuatan Egrang Tempurung}

Permainan Tradisional Cenderung Menggunakan Bahan-Bahan Yang Mudah Didapat Dan Cara Membuatnya Relatif Mudah. Berikut Ini Caramembuat Egrang Tempurung Kelapa.

a. Siapkan Setengah Bathok Yang Berasal Dari Buah Kelapa Tua. Bersihkan Serabutnya Dan Amplas Hingga Halus Agar Kaki Yang Berpijak Di Atasnya Bisa Merasa Nyaman.

b. Buatlah Lubang Di Tengah Masing-Masing Bathok Kelapa, Pada Bagian Yang Tidak Terlalu Keras. Untuk Membuat Lubang, Dapat Digunakan Paku Atau Pisau Tajam.

c. Masukkan Kedua Ujung Tali Pada Masing-Masing Lubang, Lalu Diberi Pengait Di Bawah Lubang Sehingga Tali Terkait Dengan Kuat. Untuk Pengait Dapat Digunakan Potongan Kayu Atau Bambu Pendek.Pengait Diikat Menggunakan Ujung Tali Di Bawah Lubang Pada Tempurung Kelapa. Sementara Itu, Panjang Tali Yang Digunakan Sekitar 2 Meter. Jika Menghendaki, Tali Dapat Di Potong Menjadi Dua. Kemudian Masing-Masing Ujungnya Diikatkan Pada Pengait Di Bawah Lubang Dan Ujung Tali Yang Lain Diikatkan Pada Pegangan Yang Dapat Dibuat Dari Kayu Atau Bambu.

d. Untuk Mempercantik Tempurung Dapat Dicat Atau Dilukis Sesuai Dengan Selera.

e. Egrang Tempurung Siap Digunakan.

\section{Cara Bermain Egrang Tempurung}

Cara bermain permainan tradisional egrang tempurung adalah sebagai berikut:

a. Permainan egrang tempurung dapat dimainkan sendiri atau bersama-sama, jika dimainkan secara bersama-sama, terlebih dahulu dibuat garis star dan finish.

b. Para pemain bersiap di garis star. Kedua kaki diletakkan pada masing-masing tempurung, dengan ibu jari dan telunjuk pada jari kaki menjepit tali. Sementara itu, tangan memegang tali.

c. Para pemain berjalan menggunakan tempurung

d. Pemenang dari permainan ini adalah pemain yang pertama kali berhasil mencapai garis finish.

\section{Manfaat Permainan Egrang Tempurung}

Mulyani, dalam Roftah (2019:33-34) bermain mempunyai manfaat yang besar bagi perkembangan anak. Bermain merupakan sarana untuk menggali 
pengalaman belajar yang sangat berguna dalam kehidupan sosial anak-anak, misalnya: pengalaman dalam membina hubungan dengan teman sebaya, menambah perbendaharaan kata, menyalurkan perasaan-perasaan yang tertekan, belajar untuk menghargai orang lain, belajar untuk mengikuti aturan main dari permainan tersebut, dan masih banyak lagi yang lainnya. Berikut ini manfaat permainan egrang bathok:

a. Melestarikan budaya olahraga tradisional bangsa.

b. Dapat mengembangkan berbagai macam fungsi tubuh. Diantaranya:

c. Meningkatkan keseimbangan badan anak pada saat permainan Berlangsung.

d. Mengkoordinasi antara mata tangan dan kaki anak meningkat

e. Melatih jari jemari anak

f. Meningkatkan daya tahan tubuh, dan kekuatan anak

g. Meningkatkan sikap sportivitas antar pemain atau teman.

h. Dapat menjalin hubungan persahabatan dan kerjasama yang baik.

i. Mengembangkan kemampuan penggunaan strategi dan teknik yang terlibat dalam aktivitas suatu permainan.

\section{Nilai-Nilai Dalam Permainan Egrang Tempurung}

Nilai yang terkandung dalam permainan ini adalah kerja keras, keuletan, dan sportivitas. Nilai kerja keras tercermin dari semangat para pemain yang berusaha agar dapat mengalahkan lawannya. Nilai keuletan tercermin dari keterampilan dalam menggunakan alat tempurung untuk berjalan yang memerlukan ketekunan agar seimbang dan dapat berjalan. Nilai sportivitas tercermin tidak hanya dari sikap para pemain yang tidak berbuat curang saat berlangsungnya permainan, tetepi juga mau menerima kekalahan dengan baik.

\section{Kelebihan Dan Kekurangan Egrang Tempurung}

a. Kelebihan permainan egrang tempurung

1) Dapat melestarikan budaya olahraga tradisional bangsa kepada anak-anak usia dini

2) Bahan yang digunakan mudah didapatkan di lingkungan sekitar

3) Cara pembuatan media yang mudah

4) Dapat meningkatkan kreativitas guru

5) Membantu perkembangan motorik kasar anak usia dini yaitu kordinasi antara mata, tangan, dan kaki.

b. Kekurangan permainan egrang tempurung

1) Kegiatan ini hanya bisa dilalakukan diluar ruangan

2) Membutuhkan lahan yang cukup untuk bermain 


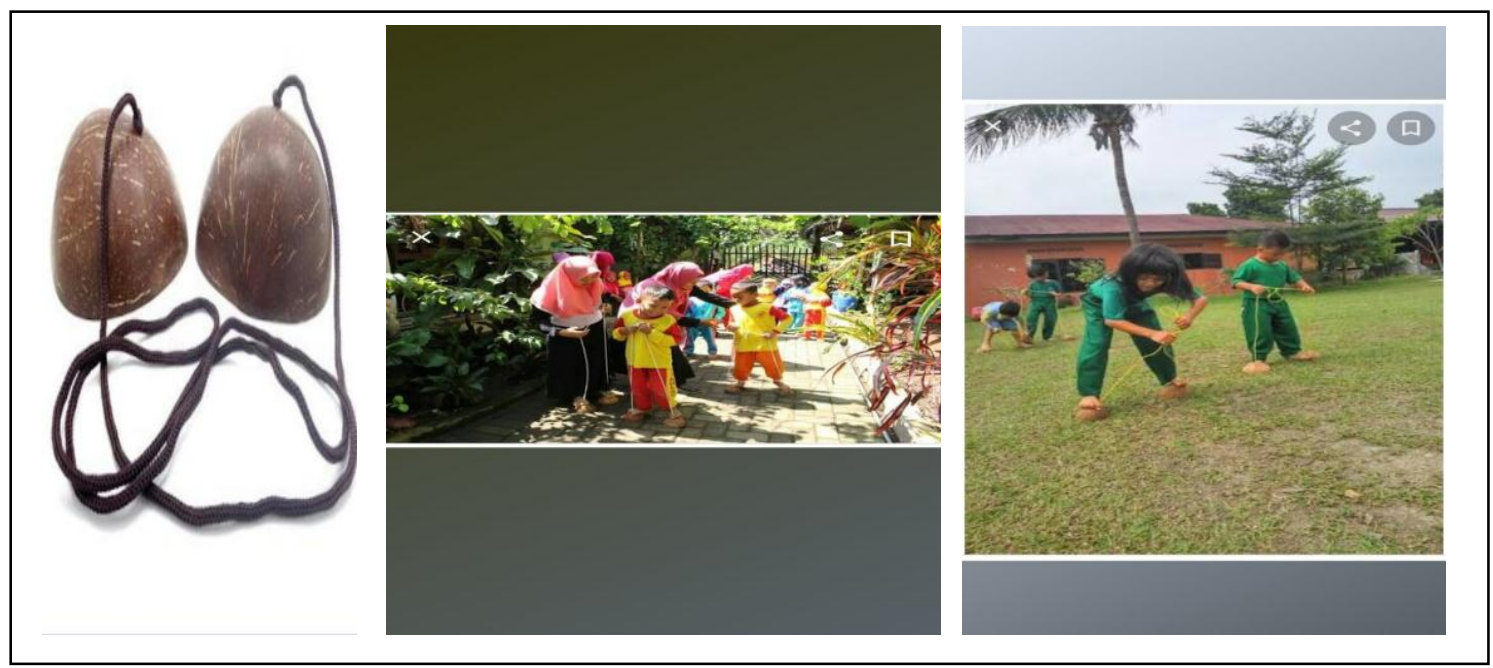

Gambar 1. Cara bermain "jalan tempurung"

Penelitian sebelumnya dilakukan oleh Putri Pulansari (2013:1), dengan judul "Penggunaan Permainan Tradisional Egrang Bathok Untuk Meningkatkan Motorik Kasar Anak Kelompok B TK Dharma Wanita Persatuan Driyorejo II Gresik". Adapun tujua penelitian ini adalah untuk mengetahui peningkatan motorik kasar yang dilakukan melalui permainan tradisional egrang bathok. Metode yang dipakai dalam penelitian ini adalah observasi. Hasil penelitian ini diperoleh dari teknik pengumpulan data, melalui teknik observas, menunjukkan terjadi peningkatan pada pencapaian perkembangan motorik kasar anak. Hal ini dapat diidetifikasi dengan peningkatan hasil rata-rata persentase pencapaian perkembangan motorik kasar dari siklus 1 ke siklus 2 sebesar 17,1\%. Berdasarkan hasil pengelolaan data tersebut, maka dapat disimpulkan bahwa kegiatan permainan tradisional egrang bathok dapat meningkatkan kemampuan motorik kasar anak yang dilakukan dengan 2 siklus dan tidak mengulang di siklus berikutnya.

Penelitian berikutnya dilakukan oleh Purwadi Saputri Agus Vicky (2016:1), dengan judul "Upaya Meningkatkan Motorik Kasar Anak Melalui Metode Permainan Tradisional Egrang Bathok Kelapa Di RA Taqwal Ilah Semarang”. Berdasarkan hasil penelitian menujukkan bahwa bahwa melalui metode permainan trasdisional egrang batok kelapa dapat meningkatkan motorik kasar anak yaitu dengan penilaian aspek keseimbangan, kekuatan, kelincahan, dan kecepatan. Hal ini menunjukkan bahwa adanya peningkatan hasil belajar motorik kasar anak yang dilakukan siklus I dan siklus II. Penelitian ini dihentikan pada pada siklus II karena sudah memenuhi indikator kinerja yang diharapkan mencapai $80 \%$.

Hasil dari penelitian selanjutnya yang dilakukan oleh Rahmawati, dkk (2019:101), dengan judul 'Upaya Meningkatkan Kemampuan Motorik Kasar Melalui Permainan Tradisional Pada Anak Kelompok B RA AN-NUR Tunjungtirto Kecamatan Singosari Kabupaten Malang”. Berdasarkan pada hasil temuan dan pembahasan dapat disimpulkan bahwa proses pembelajaran fisik motorik melalui permainan tradisional egrang batok terbukti efektif dan mampu menciptakan suasana pembelajaran yang aktif dan yang menyenangkan dalam perkembangan motorik kasar anak. Karena anakanak secara langsung terlibat (mengalami dan merasakan) bagaiamana permainan egrang batok tersebut pada masing-masing anak.Sehingga anak tidak mudah merasa bosan, sebaliknya anak antusias dalam bermain egrang batok sampai ada yang berebut dan tidak mau masuk kedalam kelas ketika jam pembelajaran telah usai. Dengan 
demikian pembelajaran fisik motorik melalui permainan tradisional egrang batok di nilai membawa dampak positif bagi hasil belajar anak, sehingga anak lebih termotivasi dan aktif.

Berdasarkan penelitian yang telah dilakukan di atas, dapat disimpulkan bahwa dengan permainan tradisional "jalan tempurung" terbukti mengembangkan perkembangan fisik motorik kasar anak, terdapat pada proses permainan berlangsung dimana otot-otot besar anak berfunngsi ketika anak berjalan menggunakan alat permainan semakin anak berjalan dan bergerak akan semakin berkembang dan semakin meningkat perkembangan fisik motorik kasar anak.

\section{F. Kesimpulan}

Berdasarkan pembahasan diatas, penulis menyimpulkan bahwa perkembangan fisik motorik kasar anak sangat penting dalam tahapan perkembangan anak. Banyak strategi yang dapat kita gunakan dalam meningkatkan fisik motorik kasar anak, salah satunya yaitu dengan kegiatan bermain karena dunia anak adalah bermain sambil belajar. Permainan tardisional 'jalan tempurung' sangat mendungkung perkembangan fisik motorik kasar anak, dimana otot-otot besar anak semakin berfungsi dan semakin berkembang. Permainan tersebut banyak disukai oleh anakanak, cara dimainkan pun sangat mudah, yaitu kedua kaki diletakkan pada masingmasing tempurung dengan ibu jari dan telunjuk pada jari kaki menjepit tali, sementara itu tangan memegang tali dan bersiap-siap untuk berjalan. semakin anak bergerak berjalan akan semakin meningkat perkembangan fisik motorik kasar anak.

\section{DAFTAR PUSTAKA}

Baan Bulu Addriana, dkk. 2020. Perkembangan Motorik Kasar Anak Usia Dini: Jurnal Bungamputi Vol 6 Nomor 1.

Erlinda, Esti. 2014. Pengembangan Motorik Kasar Anak Usia Dini Melalui Permainan "Melempar Dan Menangkap Bola". Skripsi: Universitas Bengkulu.

Hasanah, Uswatun. 2016. Pengembangan Kemampuan Fisik Motorik Melalui Permainan Tradisional Bagi Anak Usia Dini. Jurnal Pendidikan Anak, Vol 5 Edisi 1.

Kurniati, Euis. 2016. Permainan Tradisional Dan Peranannya Dalam Mengembangkan Keterampilan Sosial Anak. Jakarta: Prenadamedia Groub.

Laedy, Khusnul. 2015. Pengaruh Permainan Egrang Tempurung Kelapa Terhadap Peningkatan Kecerdasan Kinestetik Anak.Jurnal Empowerment, Vol 3 nomor 1.

Mulyani, Novi. 2018. Perkembangan Dasar Anak Usia Dini. Yogyakarta: Gava Media.

Masruroh, Handariatul. 2018. Hubungan Antara Permainan Tradisional Egrang Tempurung Kelapa Dengan Kemampuan Motorik Kasar Anak Kelompok B Di TK Taman Indria 2 Genteng Kabupatan Banyuwangi.Skripsi: Universitas Jember.

Novitasari Reni, dkk. 2019. Meningkatkan Kemampuan Motorik Kasar Anak Melalui Bermain Dengan Media Hulahoop Pada Anak Kelompok B PAUD Al-SYAFAQOH Kabupaten Rejang Lebong: Jurnal Ilmiah Potensia Vol 4 (1). 
Ismail, Muslimah Ika. 2018. Permainan Engklek Dalam Meningkatkan Motorik Kasar Anak Usia 5-6 Tahun Di AL Hikmah Kecamatan Medan Denai. Skripsi: Universitas Islam Negeri Sumatra Utara.

Purwadi, Saputri Agus Vicky. 2016. Upaya Meningkatkan Motorik Kasar Anak Melalui Metode Permainan Tradisional Egrang Bathok Kelapa Pada Kelompok B Di RA Takqwal Ilha Semarang.Jurnal Penelitian Dalam Bidang Pendidikan Anak UsiaDini.

Putri Pulansari (2013:1), Penggunaan Permainan Tradisional Egrang Bathok Untuk Meningkatkan Motorik Kasar Anak Kelompok B TK Dharma Wanita Persatuan Driyorejo II Gresik. Jurnal PAUD.

Roftah, Darajatir. 2019. Pengembangan Motorik Kasar Anak Melalui Permainan Egrang Batok Pada Kelompok B Di TK Hikmah Tazkia Salatiga, Skripsi: Institut Agama Islam Negeri Salatiga.

Rahmawati Maulidah, dkk. 2019. Upaya Meningkatkan Kemampuan Motorik Kasar Melalui Permainan Tradisional Pada Anak Kelompok B RA AN-NUR Tunjungtirto Kecamatan Singosari Kabupaten Malang.Jurnal. Ilmiah Pendidikan Islam Anak Usia Dini, Vol 1.

Riza Muhamad, Dan Ayu Swaliana, 2018. Deteksi Perkembangan Kompetensi Motorik Anak Di PAUD Nadila Kecamatan. Bebesen Kabupaten Aceh Tengah: Jurnal As-Salam Vol 2 (3)

Rinasari, Evita. 2013. Meningkatkan Keterampilan Motorik Kasar Anak Melalui Permainan Egrang Bathok Kelapa Pada Anak Kelompok B Di TK Aba Banjarharjo II Kalibawang Kulon Progo.Skripsi: Universitas Negeri Jakarta.

Sari, Puspita Dina.2019. Pengaruh Permainan Tradisional Terhadap Kemampuan Mengenal Lambang Bilangan Anak Usian Dini.Skripsi: Universitas Lampung.

Turyani, Eka Mayrawati Sri. Dan Wondal, Rosita. 2018. Pengembangan Kreativitas Pembelajaran Pada Anak Usia Dini. Jakarta: Chivita Books.

Wiyani, Ardy Novan. 2015. Manajemen Paud Bermutu. Yogyakarta: Gava Media

Zahriani Nurul Dan, Primanisa Reiska. 2020. Tindak Lanjut Hasil Asesmen Terhadap Pelaksanaan Pembelajaran Anak Usia Dini Di Taman Kanak-Kanak (TK): Jurnal Pendidikan Raudhatul Athfal. 